\title{
Retinoblastoma associated orbital cellulitis
}

\author{
Paul B Mullaney, Zeynel A Karcioglu, Antonio M Huaman, Saleh Al-Mesfer
}

\begin{abstract}
Aim-Preseptal and orbital cellulitis are rare presenting features of intraocular retinoblastoma. The objectives of this study were to determine the frequency of retinoblastoma associated cellulitis, as well as to review its clinical and histopathological features.
\end{abstract}

Methods-The medical records of 292 retinoblastoma patients in the King Khaled Eye Specialist Hospital in Riyadh, Saudi Arabia were reviewed. Those indicating a history of, or presenting with, cellulitis were retrieved and their clinical, radiological, and histopathological variables were assessed. Patients with definite extraocular tumour extension on clinical or radiological examination were excluded.

Results-14 patients were found to have retinoblastoma associated cellulitis $(4.8 \%)$; nine had bilateral and five had unilateral retinoblastoma. Conjunctival and blood cultures were performed in 10 cases and were negative. 10 children were treated with intravenous steroids, often in conjunction with antibiotics, resulting in a prompt decrease in inflammation. Three other children were treated with antibiotics alone and one received no treatment. Computed tomographic scanning depicted large intraocular tumours occupying between $80 \%$ and $100 \%$ of the globe in each case. In eight patients, periocular inflammation was radiologically interpreted as possible extraocular extension. In one patient serial computed tomographic scanning showed a reduction in intraocular calcification over time which occurred in the presence of cellulitis. 12 patients underwent enucleation and histopathological examination revealed large necrotic, poorly differentiated tumours associated with uveal involvement and early optic nerve invasion. Focal perilimbal destruction was seen in one patient, and in another peripapillary extrascleral extension was present. 12 patients are alive with a mean follow up of $\mathbf{5 6 . 4}$ months.

Conclusions-Radiological evaluation of scleral integrity may be hindered by periocular inflammatory changes. The orbital cellulitis correlated well with the presence of advanced intraocular retinoblastoma with massive necrosis and anterior chamber involvement. In the majority of patients, cellulitis was not indicative of an extension of retinoblastoma into the orbit. Intravenous steroid treatment reduced orbital inflammation, facilitating examination and subsequent enucleation.

(Br f Ophthalmol 1998;82:517-521)
Orbital cellulitis is an uncommon presenting feature of retinoblastoma. ${ }^{1-4}$ Many previously described cases have had marked associated anterior segment involvement, including corneal opacification and enlargement, glaucoma, uveitis, and rubeosis iridis. ${ }^{1-3}$ Masking of the underlying pathology can lead to delay in diagnosis and mismanagement with disastrous consequences. $^{23}$

The pathogenesis of the retinoblastoma associated cellulitis is not known. An immune mediated response, generated by a contralaterally affected eye or by necrotic tumour by products, has been suggested. Infective agents do not appear to play a role. ${ }^{1}$

We reviewed the medical records of all retinoblastoma patients with retinoblastoma associated orbital cellulitis who had presented to the King Khaled Eye Specialist Hospital in Riyadh, Saudi Arabia, between 1983 and 1996, to assess the clinical, radiological, and histopathological variables.

\section{Patients and methods}

The medical records of 292 patients in the hospital retinoblastoma registry were reviewed for cases of retinoblastoma associated orbital cellulitis. Inclusion criteria were eyelid and periorbital oedema and hyperaemia, chemosis, conjunctival hyperaemia, and limitation of extraocular motility. Patients with definite clinical and radiological extraocular retinoblastoma were excluded. Orbital cellulitis was staged according to the classification of Eustis et al. ${ }^{5}$ The clinical status of these patients on presentation was reviewed; age, sex, laterality, and family history were documented. Furthermore, the ocular findings, including the presence of opaque or cloudy corneas, anterior segment inflammatory signs, and elevated intraocular pressures (IOP) where obtained, were noted. White cell counts (WCC), the presence or absence of systemic pyrexia, and the status of blood and/or conjunctival forniceal cultures were tabulated. Treatment regimens were documented. The radiological and histopathological material was reviewed.

In all cases, radiological evaluation was performed under chloral hydrate sedation with 2 mm axial scans by a computed tomographic (CT) scanner (GE-CT 9800) with and without contrast enhancement using Omnipaque (300 $\mathrm{mg}$ iodine $/ \mathrm{ml}$ ). An estimate of tumour size and calcification was made.

The histopathological specimens had been embedded in paraffin, sectioned, and stained with haematoxylin and eosin and periodic acid Schiff (PAS). The following histopathological variables were documented: endophytic and exophytic growth, the size of the tumour (in terms of percentage of occupied vitreous 
Table 1 Clinical findings in 14 patients presenting with cellulitis associated with retinoblastoma

\begin{tabular}{|c|c|c|c|c|c|c|c|}
\hline $\begin{array}{l}\text { Case } \\
\text { No }\end{array}$ & $\begin{array}{l}\text { Sex/age } \\
\text { (months) } \\
\text { Eye }\end{array}$ & Clinical signs & $\begin{array}{l}\text { Temp } \\
\left({ }^{\circ} \mathrm{C}\right)\end{array}$ & $W C C$ & Medical treatment & Other treatment & $\begin{array}{l}\text { Current status } \\
\text { (months after } \\
\text { presentation) }\end{array}$ \\
\hline 1 & $\begin{array}{l}\text { F/12 } \\
\text { Left }\end{array}$ & $\begin{array}{l}\text { Oedematous C } \\
\text { IOP } 43 \mathrm{~mm} \mathrm{Hg}\end{array}$ & 36.5 & 16400 & $\begin{array}{l}\text { IV cefotaxime } 500 \mathrm{mg} 8 \\
\text { IV prednisolone } 5 \mathrm{mg} 12\end{array}$ & $\begin{array}{l}\text { Enucleation } \\
\text { Adjunctive chemotherapy }\end{array}$ & Alive (48) \\
\hline 2 & $\begin{array}{l}\mathrm{F} / 30 \\
\text { Left }\end{array}$ & $\begin{array}{l}\text { Quiet AC } \\
\text { IOP } 40 \mathrm{~mm} \mathrm{Hg}\end{array}$ & 36.5 & 16400 & $\begin{array}{l}\text { IV cefazolin } 100 \mathrm{mg} 6 \text {; } \\
\text { dexamethazone } 5 \mathrm{mg}, 1 \text { dose }\end{array}$ & Enucleation & Alive (50) \\
\hline 3 & $\begin{array}{l}\mathrm{F} / 12 \\
\text { Right }\end{array}$ & $\begin{array}{l}\text { Quiet AC post seg haem, } \\
\text { IOP } 17 \mathrm{~mm} \mathrm{Hg}\end{array}$ & 37.5 & 12000 & $\begin{array}{l}\text { IV ampicillin } 250 \mathrm{mg} 6 \text {; IV flucloxacillin } \\
250 \mathrm{mg} \text {. At local hospital }\end{array}$ & Enucleation & Alive (113) \\
\hline 4 & $\begin{array}{l}\text { M/16 } \\
\text { Left }\end{array}$ & $\begin{array}{l}\text { Oedematous C } \\
\text { IOP: NA }\end{array}$ & 37.5 & 19300 & $\begin{array}{l}\text { IV flucloxacillin } 500 \mathrm{mg} 6 \\
\text { Decadron } 5 \mathrm{mg} 8 \times 72 \text { hours }\end{array}$ & $\begin{array}{l}\text { EBRT } \\
\text { Adjunctive chemotherapy }\end{array}$ & Alive (108) \\
\hline 5 & $\begin{array}{l}\text { F/6 } \\
\text { Left }\end{array}$ & $\begin{array}{l}\text { Phthisis } \\
\text { IOP: NA }\end{array}$ & NA & NA & IV antibiotics at local hospital & $\begin{array}{l}\text { Enucleation } \\
\text { Adjunctive chemotherapy }\end{array}$ & Alive (35) \\
\hline 6 & $\begin{array}{l}\mathrm{M} / 24 \\
\text { Left }\end{array}$ & $\begin{array}{l}\text { Opaque C, "fluffy material" in AC } \\
\text { IOP } 24 \mathrm{~mm} \mathrm{Hg}\end{array}$ & 36.0 & 12200 & $\begin{array}{l}\text { IV cefazolin } 125 \mathrm{mg} 6 \\
\text { IV prednisolone } 2.5 \mathrm{mg} 6\end{array}$ & $\begin{array}{l}\text { Enucleation } \\
\text { Adjunctive chemotherapy }\end{array}$ & Alive (40) \\
\hline 7 & $\begin{array}{l}\mathrm{F} / 24 \\
\text { Right }\end{array}$ & $\begin{array}{l}\text { Fibrin in AC } \\
\text { IOP high }\end{array}$ & 37.5 & 17200 & $\begin{array}{l}\text { IV cefazolin } 110 \mathrm{mg} 6 \\
\text { IV prednisolone } 2.5 \mathrm{mg} 6\end{array}$ & Enucleation & Alive (44) \\
\hline 8 & $\begin{array}{l}\mathrm{F} / 24 \\
\text { Right }\end{array}$ & $\begin{array}{l}\text { Opaque C, shallow } \mathrm{AC} \\
\text { IOP } 50 \mathrm{~mm} \mathrm{Hg}\end{array}$ & 38.0 & 15000 & PO Cechlor $250 \mathrm{mg} 6$ & $\begin{array}{l}\text { Enucleation } \\
\text { Adjunctive chemotherapy }\end{array}$ & Dead (78) \\
\hline 9 & $\begin{array}{l}\mathrm{F} / 7 \\
\text { Right }\end{array}$ & $\begin{array}{l}\text { Hazy C } \\
\text { IOP } 30 \mathrm{~mm} \mathrm{Hg}\end{array}$ & 37.5 & 11700 & $\begin{array}{l}\text { IV ampicillin } 200 \mathrm{mg} 8 \text {; } \\
\text { IV prednisolone } 2 \mathrm{mg} 8\end{array}$ & $\begin{array}{l}\text { Enucleation } \\
\text { EBRT }\end{array}$ & Alive (40) \\
\hline 10 & $\begin{array}{l}\mathrm{F} / 20 \\
\text { Left }\end{array}$ & $\begin{array}{l}\text { Cell and flare in AC } \\
\text { IOP: NA }\end{array}$ & NA & NA & No treatment & $\begin{array}{l}\text { EBRT } \\
\text { Enucleation }\end{array}$ & Alive (138) \\
\hline 11 & $\begin{array}{l}\mathrm{F} / 20 \\
\text { Left }\end{array}$ & $\begin{array}{l}\text { Rubeosis iridis, shallow AC } \\
\text { IOP high }\end{array}$ & 39.5 & 17400 & $\begin{array}{l}\text { IV Kefzol } 30 \mathrm{mg} 6 \\
\text { IV gentamicin } 15 \mathrm{mg} 8\end{array}$ & $\begin{array}{l}\text { EBRT } \\
\text { Adjunctive chemotherapy }\end{array}$ & $\begin{array}{l}\text { Dead }\left(2^{\circ} \text { to }\right. \\
\text { disseminated } \mathrm{Rb})\end{array}$ \\
\hline 12 & $\begin{array}{l}\mathrm{M} / 14 \\
\text { Left }\end{array}$ & $\begin{array}{l}\text { Opaque C } \\
\text { IOP: NA }\end{array}$ & 37.4 & 15200 & $\begin{array}{l}\text { IV ampicillin } 250 \mathrm{mg} 6 \\
\text { IV prednisolone } 7.5 \mathrm{mg} 6\end{array}$ & $\begin{array}{l}\text { Enucleation } \\
\text { EBRT } \\
\text { Adjunctive chemotherapy }\end{array}$ & Alive (31) \\
\hline 13 & $\begin{array}{l}\mathrm{M} / 2 \\
\text { Right }\end{array}$ & $\begin{array}{l}\text { Opaque C } \\
\text { IOP: NA }\end{array}$ & 37.4 & 9500 & $\begin{array}{l}\text { IV prednisolone } 1.0 \mathrm{mg} 6 \times 96 \text { hours } \\
\text { IV prednisolone } 2.0 \mathrm{mg} 6 \times 48 \text { hours }\end{array}$ & Enucleation & Alive (21) \\
\hline 14 & $\begin{array}{l}\text { F/36 } \\
\text { Left }\end{array}$ & $\begin{array}{l}\text { Opaque } \mathrm{C} \text { disorganised } \mathrm{AC} \text { with } \\
\text { tumour } \\
\text { IOP: NA }\end{array}$ & 36 & 11300 & IV prednisolone $2.5 \mathrm{mg} 6$ & Enucleation & Alive (9) \\
\hline
\end{tabular}

Cellulitic eyes only described.

$\mathrm{AC}=$ anterior chamber; EBRT=external beam radiation therapy; $\mathrm{f} / \mathrm{u}=$ follow $\mathrm{up} ; \mathrm{C}=$ cornea; $\mathrm{NA}=$ not available; post seg=posterior segment; $\mathrm{WCC}=$ white cell count.

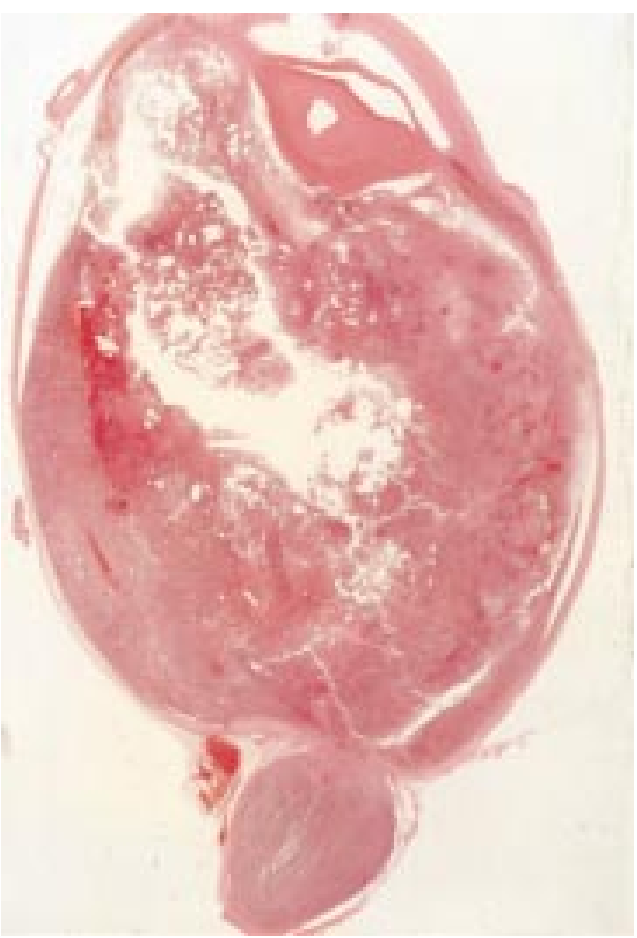

Figure 1 Microphotograph, depicting an example of extensively necrotic retinoblastoma with optic nerve and anterior chamber involvement (haematoxylin and eosin, original magnification $\times 1$ ).

cavity), the percentage of tumour necrosis, the degree of calcification, tumour differentiation, and the presence or absence of fibrosis. The extent of a tumour was established by assessing the involvement of different intraocular structures. Choroidal extension was expressed in progressive grades from I to III: grade I indicated breakage of the retinal pigment epithelium and Bruch's membrane and grade III diffuse involvement of the choroid; intermediate stages were considered to be grade II. Optic nerve involvement was expressed according to Magram's scale. ${ }^{6}$

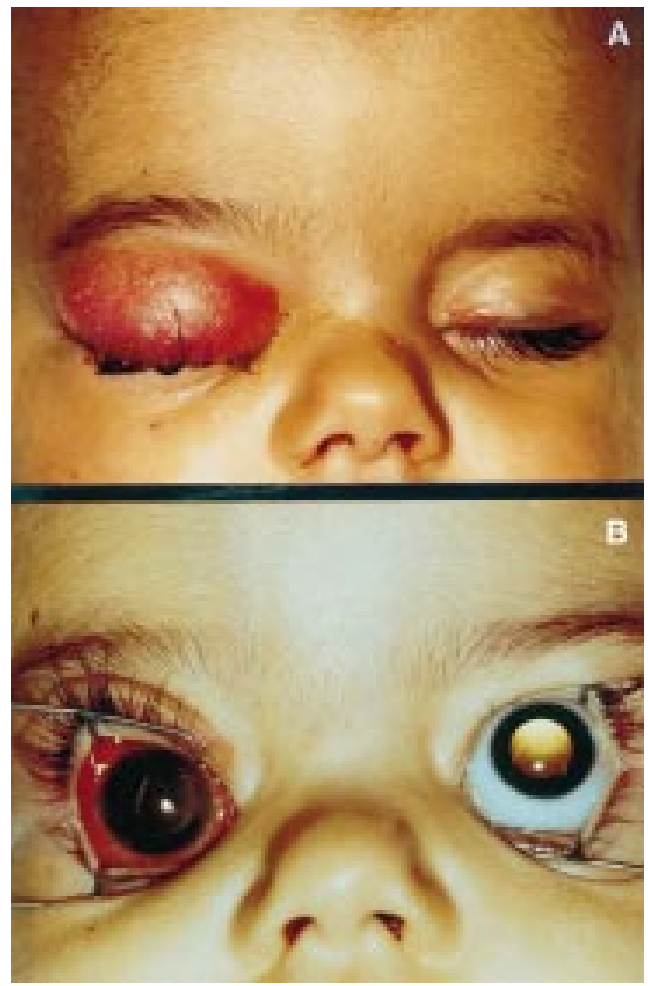

Figure 2 (A) Case 9 on presentation, with eyelid and periorbital oedema and hyperaemia. (B) Clinical resolution of cellulitis after 4 days of intravenous steroid treatment. 
Table 2 Extent of tumour spread in 12 patients with retinoblastoma associated cellulitis, based on histopathological findings

\begin{tabular}{|c|c|c|c|c|c|c|c|c|c|}
\hline Case $n^{*}$ & $\begin{array}{l}\text { Corneal } \\
\text { invasion }\end{array}$ & $\begin{array}{l}\text { Tumour cells in } \\
\text { anterior chamber }\end{array}$ & $\begin{array}{l}\text { Iris } \\
\text { invasion }\end{array}$ & $\begin{array}{l}\text { Trabecular meshwork } \\
\text { involvement }\end{array}$ & $\begin{array}{l}\text { Ciliary body } \\
\text { invasion }\end{array}$ & $\begin{array}{l}\text { Choroidal } \\
\text { invasion }\end{array}$ & $\begin{array}{l}\text { Tumour cells in } \\
\text { emissary channels }\end{array}$ & $\begin{array}{l}\text { Optic nerve } \\
\text { invasion }\end{array}$ & $\begin{array}{l}\text { Extrascleral } \\
\text { extension }\end{array}$ \\
\hline 1 & - & yes & - & yes & yes & $3+$ & - & $3+$ & - \\
\hline 2 & - & yes & - & - & - & $1+$ & - & $1+$ & - \\
\hline 3 & - & yes & - & yes & yes & $3+$ & - & - & - \\
\hline 5 & - & yes & yes & yes & yes & $3+$ & - & $1+$ & - \\
\hline 6 & - & yes & - & - & yes & $3+$ & - & $2+$ & - \\
\hline 7 & - & - & - & - & - & - & - & - & - \\
\hline 8 & - & - & - & yes & yes & $3+$ & - & $3+$ & - \\
\hline 9 & - & yes & - & - & - & - & - & - & - \\
\hline 10 & - & - & - & - & yes & - & - & - & - \\
\hline 12 & yes & yes & yes & yes & yes & $3+$ & yes & - & yes \\
\hline 13 & - & $-\dagger$ & - & - & - & $2+$ & - & - & - \\
\hline 14 & - & yes & yes & yes & - & $3+$ & yes & $3+$ & yes \\
\hline
\end{tabular}

^Patients 4 and 11 not enucleated therefore not included.

†Polymorphonucleocytes in AC.

\section{Results}

Fourteen patients (10 females, four males) with clinical manifestations (12) or history (two patients were initially treated by referring ophthalmologists in local hospitals) of retinoblastoma associated orbital cellulitis were studied. The frequency was calculated to be $4.8 \%$. Age at presentation ranged from 2 to 36 (mean 17.6) months. Twelve patients are known to be alive with a follow up ranging from 9 to 138 (mean 56.4) months from presentation. A positive family history for retinoblastoma was documented in one patient (case 7).

Bilateral retinoblastoma was a feature in nine patients; five were unilateral. In the group with bilateral retinoblastoma, the fellow eye in eight patients out of nine was either ReeseEllsworth stage IV or stage V; only one (case 6) had a contralateral retinoblastoma, which was staged as IA. For the purposes of this report only the affected cellulitic eye will be alluded to. In all cases examined the cellulitis corre-

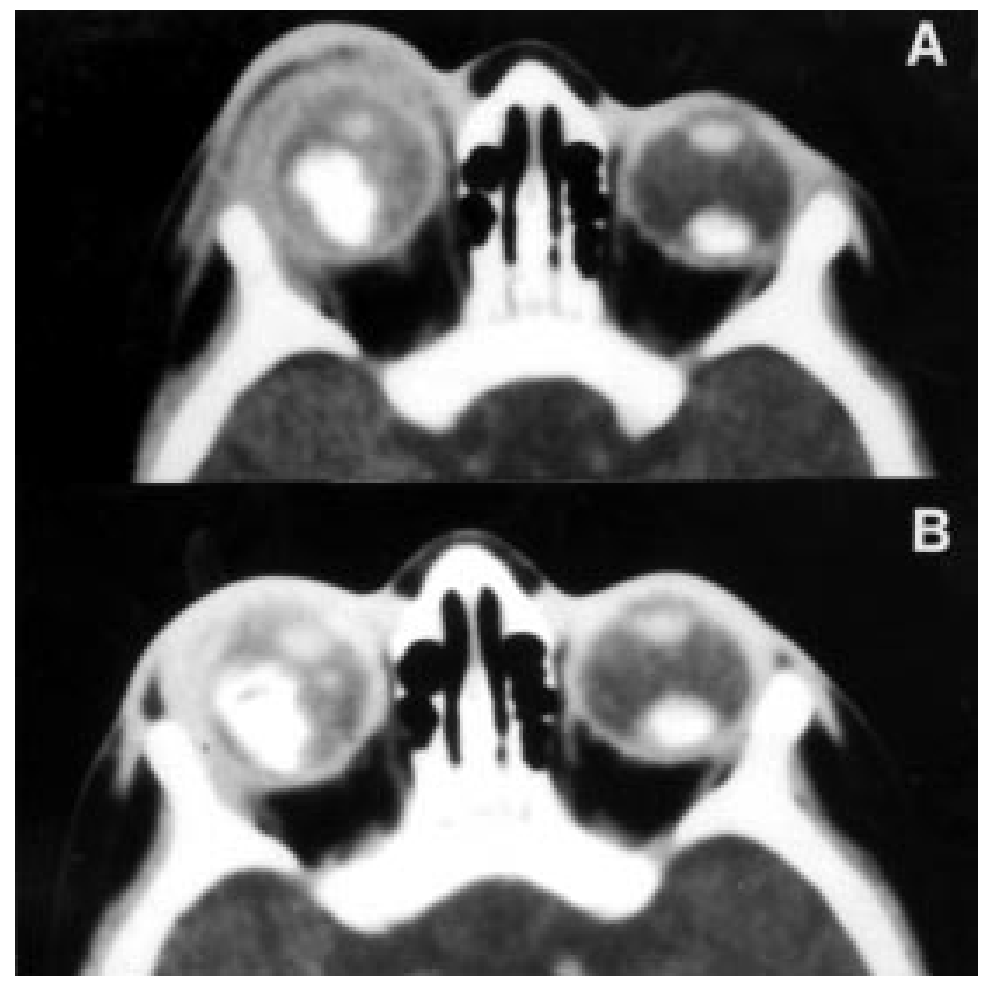

Figure 3 (A) Computed tomograph scan of case 9, with retinoblastoma associated cellulitis on admission. (B) CT scan of the same patient after 4 days of treatment, with decreased orbital oedema. sponded to the inflammatory oedema stage (stage II) seen in bacterial orbital cellulitis. ${ }^{5}$ Of the 12 patients (two initially commenced their treatment at local hospitals) who presented with acute cellulitis, 10 had inflammation of the anterior segment; only in two patients was the anterior segment quiet (Table 1 ).

Two children exhibited pyrexia on admission with rectal temperatures of $38^{\circ} \mathrm{C}$ and $39.5^{\circ} \mathrm{C}$. White cell counts on admission, ranged from 9500-19 300 (normal 3500-11 000). No WCC remained elevated for more than 3 days after admission. Cultures of conjunctiva and blood (obtained in 10 out of 14 cases and not in all patients because of differing routes of presentation) failed to reveal any growth.

In every case, the computed tomograph (CT) scan demonstrated a large intraocular tumour filling $80-100 \%$ of the globe associated with orbital oedema (Fig 1). In eight patients possible extrascleral extension was reported but not confirmed by pathological examination of the subsequently enucleated globe. In the two patients, where extrascleral extension was proved pathologically, there was no correlation between the radiologically suspicious area and the area through which pathologically proved extension had occurred.

Histopathologically, all eyes showed advanced intraocular tumour growth with very extensive tumour necrosis (Fig 1), with the exception of case 2 where only $50 \%$ of the tumour was necrotic. Table 2 shows the extent of intraocular involvement. Focal extraocular extension was seen inferior to the limbus in case 12, and around the optic nerve in case 14 .

Enucleation of the affected eye was performed in 12 children. Enucleation was facilitated by the prior intravenous administration of steroids and wide spectrum antibiotics. In general, intravenous prednisolone $1 \mathrm{mg} / \mathrm{kg}$ was administered which was increased to 1.5 $\mathrm{mg} / \mathrm{kg}$ if resolution was slow. The variation in treatment regimens as seen in Table 1 reflects the retrospective nature of the review and the differing physicians involved in delivering care to these children. In all instances, within 5 days the oedema was reduced clinically following this treatment (Figs 2 and 3). This reduction in inflammatory swelling and hyperaemia was helpful during the enucleation procedure, allowing a good length of optic nerve to be removed with each globe. External beam radiation therapy (EBRT) alone (4000 cGy and 


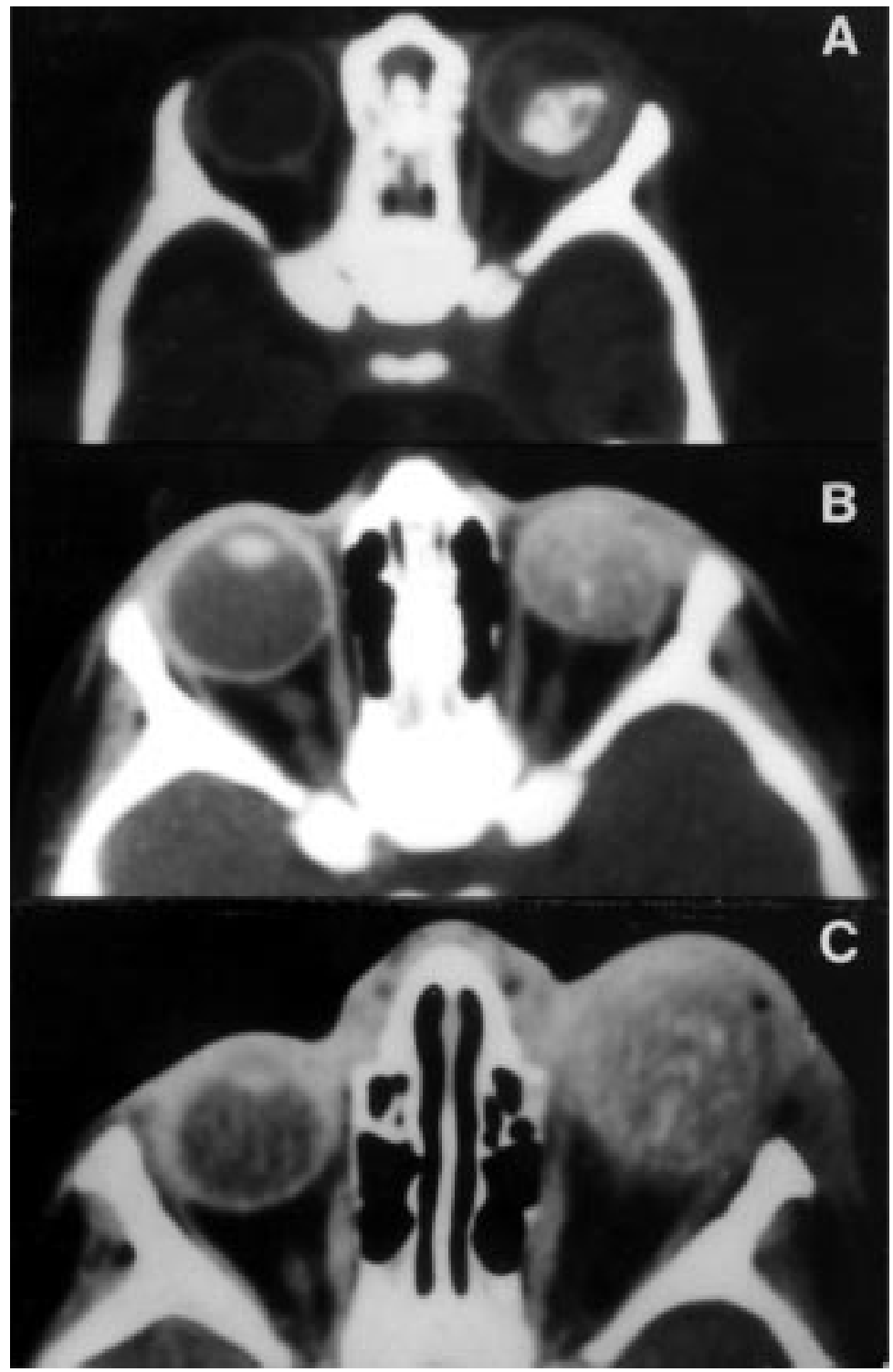

Figure 4 (A) Computed tomograph (CT) scan of case 12 on admission, depicting calcification in a relatively discrete lesion. (B) Repeat CT scan 1 year after initial presentation, revealing phthisis and almost total disappearance of calcification. (C) CT scan 14 months after initial presentation, showing buphthalmos and cellulitis.

5000 cGy) was administered to two patients. Both eyes subsequently became phthisical. One of these children died (case 11).

\section{Discussion}

Orbital cellulitis is an uncommon presenting feature of retinoblastoma and it clinically corresponds with the inflammatory stage (stage II) of bacterial orbital cellulitis. ${ }^{5}$ Conjunctivitis, steamy corneas, uveitis, rubeosis iridis, and elevated IOP are often associated with retinoblastoma associated cellulitis. ${ }^{78}$ All may coexist and may mask the underlying diagnosis. A CT scan helps establish the diagnosis and clarify whether or not extraocular extension is present. Where cellulitis coexists the inflamed appearance of the orbit may suggest extraocular extension, particularly if the sclera is thickened. Shields and co-workers have reported that soft tissue swelling is often considered to indicate extraocular extension. ${ }^{1}$ In our review eight of 12 patients were reported radiologically as having extrascleral extension in areas which subsequent histopathological examination of the enucleated globes failed to substantiate. Case 10 was referred for EBRT, presumably to reduce orbital tumour load, because on CT scan it was felt that the patient had extraocular extension.

The use of intravenous steroids with broad spectrum antibiotics diminished orbital swelling markedly. In cases 13 and 14 intravenous steroids alone were used with good results and without the development of infections. Anterior segment activity also decreased with steroid use (as seen in case 6), thus making examination easier. The reduction in preseptal swelling was very apparent clinically and on CT scan following intravenous steroid administration. Resolution of periorbital swelling can be appreciated radiologically but is not as dramatic as that in the preseptal compartment. The decrease in preseptal and periorbital swelling ensured that the enucleation that followed was technically easier to perform. Enucleation for retinoblastoma requires a long optic nerve stump which may be difficult to obtain, particularly in young patients and in the presence of orbital oedema. ${ }^{9}$

Ellsworth reported two children with both cellulitis and retinoblastoma, in one of whom the cellulitis resolved without antibiotics. ${ }^{4}$ In our series, case 3 presented partially treated, and although marked lid swelling was still present, no further antibiotics or steroids were given and resolution occurred spontaneously in less than a week. However, we feel that several days of steroid treatment expedites resolution. Although resolution may take up to 5 days and thus expose the child to further risk, we felt that the resulting ease of enucleation and retrieval of a good length of often involved optic nerve was preferable.

The aetiology of retinoblastoma associated cellulitis is unknown. Our patients had very large intraocular necrotic tumours with multiple areas of calcification. It is possible that tumour necrosis and the subsequent leaching of necrotic products from the eye is responsible for the cellulitis. Most of our cases had choroidal invasion although no tumour cells could be documented histopathologically within the scleral emissary vessels.

The majority of our patients had anterior segment involvement. Haik and co-workers reported that where anterior chamber extension was present $77 \%$ of patients had massive ciliary body involvement. ${ }^{10}$ It is also suggested that necrotic changes occurring in the ciliary body and iris root trigger an inflammatory response in adjacent orbital soft tissues. ${ }^{10} 11$ Many of our patients had tumour cells in the anterior chamber and trabecular meshwork. In our series, elevated IOP was a feature in seven patients. Angle closure glaucoma was the cause in two cases (cases 1 and 8). Another possible route for necrotic tumour debris to leach out of the eye is through the trabecular meshwork. The elevated IOP would suggest that something (possibly tumour cells or tumour necrotic products) was blocking trabecular channels of the other five patients. 
In case 12 , serial CT scans suggest that marked intraocular changes may occur over time in eyes with advanced tumours. In the first scan (Fig 4A) the tumour and focal calcification could be clearly visualised. Follow up scans performed 12 and 14 months later demonstrated a change in eye size and a decrease in intraocular calcification with generalised intraocular opacification (Figs 4B, C). This child had a 12 month history of endophthalmitis before presentation, as the parents refused enucleation. It is tempting to speculate that the changes in intraocular contents seen in this child were responsible for the cellulitis.

Our own and previous studies suggest that cellulitis does not necessarily indicate extension into the orbit. ${ }^{1}$ Some patients, however, may well have coincidental focal areas of extraocular extension which cannot be detected by clinical examination, as evident in cases 12 and 14 . Our 14 cases cover a spectrum of advancing disease from case 2 , with minimal anterior segment activity, the majority with intraocular disease and anterior segment involvement, to cases 12 and 14 with anterior segment involvement and nodular extrascleral extension. In some cases extraocular extension and intraocular necrosis can proceed together and trigger orbital inflammation, as suggested by Meir and co-workers. ${ }^{11}$

Most (12/14) of our patients are alive without clinical evidence of metastases; case 11 with a phthisical eye is dead. This underscores the danger inherent in leaving irradiated and presumed treated phthisical eyes in site. This is clearly shown in case 10 where after EBRT viable tumour cells were present in the ciliary body.

In conclusion, orbital cellulitis-like presentation in retinoblastoma does not necessarily indicate extrascleral extension of tumour. However, it correlates well with the presence of advanced intraocular disease. The sclera may be radiologically indistinct, as a result of periorbital inflammation, thus increasing the suspicion of extraocular extension which is usually not confirmed histopathologically. The cellulitis may be of inflammatory origin, probably secondary to intraocular episodes of infarction leading to tumour necrosis and calcification. In our experience intravenous steroids, with or without broad spectrum antibiotic coverage, are helpful in decongesting the orbit and facilitating subsequent enucleation.

The authors would like to acknowledge the help of Don Kikkawa, MD, and Hans Olivecrona, MD.

1 Shields JA, Shields CL, Suvarnamani C, et al. Retinoblastoma manifesting as orbital cellulitis. Am $\mathcal{f}$ Ophthalmol 1991;112:442-9.

2 Andrew JM, Smith DR. Unsuspected retinoblastoma. Am $\mathcal{f}$ Ophthamol 1965;60:536-40.

3 Binder PS. Unusual manifestations of retinoblastoma. Am $\mathcal{F}$ Ophthamol 1974;77:674-9.

4 Ellsworth RM. The practical management of retinoblastoma. Trans Am Ophthalmol Soc 1969;67:462-534.

5 Eustis HS, Armstrong DC, Buncic JR, et al. Staging of orbital cellulitis in children: computerized tomography characteristics and treatment guidelines. F Pediatr Ophthalmol Strabismus 1986;23:246-51.

6 Magram I, Abramson DH, Ellsworth RM. Optic nerve involvement in retinoblastoma. Ophthalmology 1989;96: $217-22$.

7 Manschot WA. Difficulties in the clinical diagnosis of retinoblastoma. Ophthalmology 1956;32:162-4.

8 Richards WW. Retinoblastoma simulating uveitis. $A m$ f Ophthalmol 1968;65:427-31.

9 Shields JA, Shields CL, De Potter P. Enucleation technique for children with retinoblastoma. $\mathcal{F}$ Pediatr Ophthalmol Strabismus 1992;29:213-5.

10 Haik BG, Dunleavy SA, Cooke C, et al. Retinoblastoma with anterior chamber extension. Ophthalmology 1987;94: 367-70.

11 Meir AB, Bardenstein DS, Peiffer RL. Retinoblastoma presenting with orbital cellulitis: A mechanistic hypothesis. Invest Ophthalmol Vis Sci 1995;36:S492. 